\title{
Unmediated Religion: Individualism, the Mediatic Revolution, and the New Religious Deal
}

\author{
Patrick Laude
}

\begin{abstract}
This paper examines some of the implications of globalization and the media revolution of the last decades on the shaping of religious self-definition and practices. It highlights the role of individualism as value and communication as principle of truth in the formation of a new religious consciousness. It is argued that these vectors of transformation have contributed to bring about an unmediated religious experience that shuns sacramental and institutional intermediaries. Both neo-evangelical Christianity and Islamic puritan reformist bear witness to such transformations.
\end{abstract}

Index Terms-Christianity, contemporary religion, globalization, individualism, Islam, media, Christianity, Islam.

\section{INTRODUCTION}

This paper delves into the dialectics of contemporary discourses of human universality and claims of exclusive identity in the religious domain. It proposes a reading of a few central aspects of post-traditional religious forms of thinking and acting in light of this dialectics. Furthermore, it is an attempt at situating these new religious views and practices within the context of the media and digital revolution of the last decades. Our contention is that the latter have facilitated the crystallization of a new religious contemporary consciousness by placing emphasis on the individual and communicativeness as criteria of truth. We further suggest that these forms of new religious understanding proceed from a radical breaking away from traditional norms, which highlighted the central function of hermeneutic and sacramental intermediaries.

The modern world can be characterized by a move toward a global and universal horizon of meaning as a result of the increase of information and communication produced by the exponential development of media technology. In addition, the globalization of economic and socio-political issues has resulted in the emergence of powerful challenges to particularizing cultural identities, testing their ability to survive, integrate the worldwide network of exchanges, or transform. Our purpose is to sketch a few reflections upon the nature of this universal horizon, its foundations, and its limits, but also to articulate its connection with the religious revolution of the 20th-century, one characterized by the "fundamentalization" and "evangelicalization" of religion. These terms broadly refer, in our context, to the two primary phenomena, alternately opposed or conjoined, of a formal ideologization and a private individualization of religion.

Manuscript received February 1, 2013; revised April 1, 2013.

Patrick Laude is with Georgetown University, USA (email: laudep@georgetown.edu

\section{Communication as VAlue}

Our initial allusion to increased means of communication could lead one to think of the contemporary universalist bent as primarily structural and centered on process since media, whether electronic or digital, would appear prima facie to be "value free". However, this would be ignoring two factors: first, it seems impossible to detach the media revolution from a vision of reality which is germane, if not inherent, to it, and second, it may be argued that those media, or the most globally pervasive among them, are the primary conveyors of an explicit or implicit discourse on values that tends to function as the universal horizon of most modern aspirations. To be more specific, the vision inherent to the technologies of communication favors and tends to realize instantaneousness, ubiquity and, both as a cause and a consequence of the latter, the primacy of communication as value, and not merely as means. As for the primary content of information itself, it may be characterized, at least formally, by an emphasis on the individual as an autonomous center of perception and decision. This pre-eminence of the individual is epitomized by the seemingly unbound array of choices that are provided on the internet, in a largely unmediated, unfiltered, and nonhierarchized way. While the contents of information may be explicitly contrary to the principle of individualism or the rights of the individual as an autonomous entity --since these contents can be just anything, they still presuppose that it is the individual, in front of his or her monitor or cell, who opines to, rejects, selects and ultimately defines the references that structure his or her vision of reality. The primary vector of information is therefore the ideal of freedom as a potentiality limitless horizon of transmission and exchange. Individual autonomy is thus the prime value attached to the universalist bent of contemporary media. Furthermore, it can be argued that communication is the only universal truth, not in the classical philosophical sense of an adaequatio between the knower and the known, but in the sense of a never ending process of exploration and communication. Error, by contrast, or ignorance, lies in that which obstructs the flow of communication and hampers the informational move toward the universal; hence the rejection of any manifestation of "static" and "essentialist" thinking that would refer to immovable, eternal and transcendent principles.

In such a context, religious dogmas and traditional institutions appear as contrary to the pervasive understanding of truth as process since they refer, in one way or another, to an unchanging set of propositions and magisteria that claim to hold authority ever and everywhere. Religious metaphysics is not given to historical and social 
relativization since it is anchored in transcendence, even though its expressions may vary with time through conceptual elaboration and circumstantial adaptations. By contrast with these "essentialist" figures of truth, the new paradigm highlights communication as the very truth of an unending process of extension of knowledge informed by virtually unlimited information. It is, moreover, open-ended and free from any transcendent and mediating principle or agency of epistemological validation.

\section{RELIGIOUS RESPONSES}

In this contemporary configuration, the moral and social primacy of collective particularisms, such as pertain to cultures, nations, ethnic groups and the like, has been gradually and often surreptitiously replaced by a new individualistic paradigm. This shift has perhaps been more clearly marked in the religious domain than anywhere else, as argued by Peter Berger in his sociological analysis of the "individualization" of religious self-definition. [1] This does not mean that collective religious identities have disappeared, but simply that the center of self-identification of believers has moved away from a holistic definition in which the collective had precedence over the individual to one in which this situation is reversed. Thus, individualism has eventually supplanted "holism" in the sense in which the sociologist Louis Dumont defined these terms as sociopsychological paradigms in which "value" is placed respectively in the individual or in the social whole. [2] Indeed, socio-economic mobility, the homogenization of lifestyles and a global culture of individualism have resulted in a weakening of holistic bonds, although the rise of individualism actually predates the era of the so-called "flat world" [3] and has been variously or conjointly attributed to such diverse factors as the advent of modern democracy, the rise and spread of the industrial revolution, or even the emergence of the Christian faith inasmuch as it coincided with the concept of "otherworldly individual" through a privileged relationship with Divine transcendence. [4]

Partly in reaction to the new paradigm of "communication as truth" religious "universals" have tended to harden as monolithic, formally absolutistic and literalistic, sets of beliefs and practices. This accounts for a necessary but often overlooked distinction between "contemporary fundamentalism" and traditional religion. Whereas traditional universality, whether Buddhist, Christian or Islamic, had tended hitherto to involve a recognition of diversity -both horizontal and vertical-within its fold, the new religious consciousness tends to reject any diversity as a betrayal of the integrity of its universals. While "horizontal diversity", i.e. the diversity of perspectives and interpretations existing within the tradition, was confined within a framework of orthodoxy and not exclusive of acrimonious debates, it nevertheless entailed the recognition that the tradition "transmits itself as something alive, since it is a ceaselessly renewed inspiration, and not a funeral cortege or a register of conformist opinions." [5] By contrast with the latter understanding of tradition, religious identity has largely become connected to a literal and formal definition of religion sedimented in monosemic statements of faith and prescriptions. Thus, for example, much of contemporary Islamic discourse entails a concept of the unity of the community that would be more accurately characterized as uniformity. In parallel, the sense of Islamic collective identity vehemently excludes any plurality of interpretations and degrees of understanding. This means that in order to resist the push toward "individualist universality" collective identitarianism "absolutizes" itself as a one-dimensional and monolithic reality ignorant of the traditional integration of a plurality of levels of identity, or plural identity -what we could call "vertical diversity", as well as unreceptive, if not hostile, to any measure of cross-cultural and cross-religious fertilization. [6] Whereas a medieval identity involved a multilayered and organic sense of belonging that spanned from local centers such as family, corporation and regional ethnicity, language and culture to the more encompassing religious circles of creed, contemporary national and religious identitarianism, by contrast, tends to claim a more or less exclusive role in defining identity. Thus Christian or Muslim identity has become more and more independent from, and severed from, regional, native identities on the one hand, or, in a seemingly contradictory manner, part and parcel of an exclusive ethnic and national identity that has de facto absorbed it into its fold. Islam, for example, may become a source of exclusive identity that affirms itself, on the global scene, through ubiquitous symbols such as relatively new and standardized forms of hijab or burqa. But on the other hand, particular ethnic and national groups may identify Islam with a particular people like in Malaysia, were to be a Muslim and to be Malay refers to a self-same identity. Either way, identity is built on a focal affirmation or a local self-definition more and more exclusive of any other levels or areas of identity. The "universalization" of Islam in a cosmopolitan context, for instance, tends to free Islamic identity from the limitations, but also and perhaps above all from the integrating power of its plural traditional cultural contexts. This can be, in the best possible case, an opportunity for a spiritual renewal by contact with the universal core of the tradition, but also, in the worst and arguably much more frequent scenario, an uprooting that unduly abstracts and flattens religious identity, making it a prey for ideologization. In the latter case, a new sense of religious identity emerges as antagonistic vis-à-vis any organic, traditional, commentarial and institutional mediation in a way that is structurally akin to twentiethcentury revolutionary political movements. This process results, for example, in a transformation of Islam into Islamism, a linguistic shift that is indicative of a profound mutation in the way religion is understood both from within and from the outside.

\section{RELIGION, IDEOLOGY Ad TRADITIONAL MEDiATIONS}

The transformation that we have just highlighted may be deemed to be both partly a cause and a consequence of the mediatization and globalization of religion and the primacy of communication as truth and individualistic value. Our argument is that it places the emphasis on the individual as a subjective and emotional locus of religious consciousness on the one hand, and on the formal "syllabification" and "ideologization" of religious creeds on the other hand. The 
two ultimate values, i.e. the individual and communication, become the prime movers of the religious identity. They could be symbolized by instances of revivalist emotional exaltation on the one hand, and occurrences of "formatted" predication on the other hand.

Historically, sacred and sacramental intermediaries functioned as a kind of isthmus between universality and particularity. Their function was to prevent universals from becoming abstract, whether as theological or legal forms, while keeping particularity from falling into individualism and mere psychology. This has been, by and large, the role of the Prophet and its spiritual descendants in Islam and that of the Church and its saints in Christianity. The Prophet's spiritual function, besides that of being a messenger of the Word, was to "give life" to what could remain a mere religious syllabus. His exemplar facilitated the individual integration of the universal truth. Without him and his spiritual and moral lineage of men and women, without the saints, the truth would have been desiccated into a formal system. In this sense, the Prophet and his heirs have given presence to the truth. Conversely, the Church functioned as dogmatic and theological interpreter preventing the spiritual presence of Christ from being confused with the potential whims and illusions of experiential subjectivity. In other words, in its most fruitful forms, it has given a framework of truth to divine presence.

Now one can note that contemporary religious movements, whether they are akin to fundamentalism or revivalism/evangelicalism, aim at belittling or eliminating the role of spiritual and institutional intermediaries. In contemporary Islam, the literalist fear of worship of any human agency that lies at the core of puritanical reformism has greatly contributed to a reduction of the Prophet's role to that of a passive "medium" of Revelation and a formal instructor. The dimension of exemplary spiritual and moral presence of the Prophet has tended to recede, or even to be discarded with suspicion, as more and more emphasis has been laid on the pure transcendence of God as a rational object and law-giving ultimate. Furthermore, the very notion of sanctity has mostly been evacuated on the grounds that God is the only Holy One or the only Protector (Walī). Analogically, but in reverse way as it were, the intellectual, spiritual and sacramental mediation of the Church and its magisterium has been either diluted or rejected. This reduction or expulsion is based on a number of contemporary factors such as the distrust of any dogmatic authority, an increased awareness of institutional abuses, or else a democratic discomfort with liturgical mystery and theological authority. It is the individual and his or her subjective experience of Christ that lies, therefore, at the core of most of contemporary Christianity.

This is not to say that modern forms of fundamentalism and evangelicalism do not boast their own intermediaries, but these intermediaries are either merely legal and formal, or else psychological and social. The legal scholar, either traditionally trained or ---as is more and more often the case-- self-styled, is consulted in matters of orthopraxy, and the internet itself bears witness to such recourse down to the lowest minutiae; as for the church, it has more and more been understood as a social assembly and a support system. Although contemporary neo-evangelicalism presents us with the outstanding phenomenon of the Bible as intermediary par excellence, it must be stressed that the contact of the believer with the Bible tends to be unmediated. The patristic and commentarial tradition is ignored, or rejected as irrelevant, and replaced by individual reading and interpretation, while a psycho-social and discussant contact with vernacular, sometimes simplified if not trivialized, version of the scriptures is substituted to the sacramental and symbolic, or anagogic, dimension of the text, not to mention the disregard of Hebrew hermeneutical tradition. Similarly, in reformist and puritanical Islam, and in contemporary Islam at large inasmuch as the latter has been largely reshaped and informed by the former, the Quran has undoubtedly remained a central mediation. However, it is by and large the linguistic, literalistic and one-dimensional approach of the sacred text that predominates. The text tends to be limited to a singleminded, reductive and literal reading, the whole focus of which is on formalist orthopraxy and what could be coined as "dogmatic rationalism." Even though the "sacramental" dimension of the Quran is not totally evacuated, since the Book remains, formally, the Word of God, its psalmody and reading is commonly reduced to a matter of quasiquantitative merit or aesthetic virtuosity. The plurality of levels of meaning, even though explicitly taught by validated prophetic traditions, remains largely ignored, when it is not radically discarded as mystical "innovation." In the same anti-mediating spirit, both Evangelical and Islamist critiques of tradition share in a rejection of institutional and saintly intermediaries. Evangelicals do so by emphasizing the "personal" aspect of the encounter between the soul and God, and Islamist Reformists look with an intense suspicion, if not downright hostility, at any traditional mediations that would alter the pristine and unambiguous "evidence" of the Quran and the Prophetic tradition. These two respective tendencies are indeed not immune from the pitfalls of "psychologization" on the one hand, and "ideologization" on the other hand. In the first case, there is a tendency to reduce the Divine to emotional and psychological concomitances of what is experienced individually and interpreted as Grace. In the second case, the rejection of all modes of spiritual presence of saintly presence, such a shrines, hermeneutics of spiritual interiorization and the like, results in literalism and reification which, in the context of a religious law, can all too easily open onto political ideologization or recuperation. On the one hand it seems that an over individualized immanence has jeopardized the sense of divine transcendence, while on the other hand an abstract transcendence has contributed to erase the transformative function of immanence.

\section{CONCLUSION}

Contemporary individualism highlights the rejection of intermediaries since the individual is the autonomous locus of determination of truth. Moreover, the various electronic means of communication make it possible for any individual to by-pass the institutional mediations of traditional authority, assuming they are still available, or even to introduce new, formatted, channels of information as 
substitutes. On the surface, religious collective identities may still seem to rely on authoritative intermediaries, but it is in fact less and less so, given the "flattening" of religious consciousness, i.e. the triumph of a monolithic literality that requires no mediums of interpretation, the privatization of religious identity, and the socio-political or cultural formatting of religion as a mediatized item. Thus, it appears all too clearly that the function of traditional mediations, one that had hinged upon the need to preserve religion from both psychological subjectivism and objective ideological systematization, lies in clear tension, not to say opposition, to the individualistic and informational thrusts of the contemporary concepts of truth.

\section{REFERENCES}

[1] K. Thompson, Emile Durckheim, Routledge, 2002, pp.136.

[2] L. Dumont, Essays on Individualism, University of Chicago Press, 1986.

[3] T. L. Friedman, The World Is Flat: A Brief History of the Twenty-First Century, Douglas and McIntyre, 2000.
[4] L. Dumont, Essays on Individualism, pp. 23-59, 1986.

[5] H. Corbin, En Islam Iranien, Paris: Gallimard, 1971, vol. 1, pp. 33.

[6] L.-S. Claude, Race and History, Ulan Press, 2012.

Patrick Laude has been teaching at Georgetown University since 1991. Since August 2006 he has been on the faculty of the School of Foreign Service in Qatar, where he teaches theology and humanities courses. A former student of the Ecole Normale Supérieure, he earned a M.A. in comparative philosophy from the University of Paris IV Sorbonne in 1982, and a doctorate in French literature from Indiana University in 1985. Professor Laude's scholarly interests and output lie in comparative mysticism, the relationship between poetry and mysticism, and Westernrepresentations and interpretations of Islamic and Asian contemplative, mystical and wisdom traditions. He has extensively written and lectured on eminent and original figures of European spirituality such as Jeanne Guyon, Fénelon, Simone Weil, and Louis Massignon. Laude has authored over ten books and monographs including: Pathways to an Inner Islam, Albany: SUNY Press, 2010, Louis Massignon: The Vow and the Oath, London: Matheson Trust, 2011, Pray Without Ceasing: The Way of the Invocation in World Religion, Bloomington, Indiana: World Wisdom, 2006, Divine Play, Sacred Laughter and Spiritual Understanding. New York: Palgrave McMillan, 2005, and Singing the Way: Insights in Poetry and Spiritual Transformation. Bloomington, Indiana: World Wisdom, 2005. 